\title{
LESSON 139
}

Test your Skill

10 minutes.

MARGINS: $25 \mathrm{~mm}$ or 1 inch.

Keep the right margin as straight as possible.

Use double-line spacing.

T31 - SI 1.32
There are many banks in this country and almost all are owned by shareholders and have limited liability. Sometimes these are known as Joint Stock Banks. Outside this group is a group of private banks and such banks as the Trustee banks which cater for the small saver.

The largest bank in the country is the Bank of England, and this Bank is owned by the nation - in other words it has been nationalized. The Bank of England is at the very heart of the English banking system and all the Joint Stock Banks, who are members of the London Clearing House System have, by law, to keep accounts at the Bank of England.

One of the many jobs the Bank of England does is to see to the issue of notes and coins in England and Wales, though not for the Isle of Man or Scotland. When a bank requires a sum of money, it cashes a cheque at the Bank of England. It is given new notes direct from the printing works or freshly minted coins from the mint. The new money may well be given to customers of the Joint Stock Bank when they in turn go to draw out money. The banks tend to act like sorters of money and where possible they will reissue old notes and coins but hand over new when the old money in the tills is soiled to a point where it needs replacing. When the banks in turn have money to pay into the Bank of England, they pay in their old notes and coins and are credited with the total. The soiled notes are then destroyed and the coins melted down.

Another function of the Bank of England is that of Bank to the Government. Taxes are paid into various Governmental accounts and payments made from them as the need arises. If there is not enough money in the accounts at any one time to pay all the bills the Bank can arrange loans by the issuing, at interest, of Gilt Edged Securities on the Money Market.

All the gold reserves of the country are managed by the Bank of England acting for the Government. The Bank is also responsible for representing the Government at meetings with other Central Banks and arranging international loans when a Balance of Payments crisis threatens the economy. Payments, of various kinds, are made - interest on loans and the debts incurred in times of crisis to name but two. The Bank deals in the International Money Markets to steady exchange rates, an important factor in encouraging trade.

Are you still using a backing sheet to protect the platen? 